\author{
Doi 10.5943/ppq/8/2/5 \\ Copyright $(9)$ Agriculture College, Guizhou University
}

\title{
First report of squash leaf curl virus detected in Proboscidea louisianica in Mexico
}

\section{Díaz-Nájera JF $\mathbf{J F}^{1,2}$, Ayvar-Serna $\mathbf{S}^{2}$, Vargas-Hernández $\mathbf{M}^{3 *}$, Sahagún- Castellanos $\mathbf{J}^{1}$, Alvarado-Gómez $\mathrm{OG}^{4}$, Tejeda-Reyes $\mathrm{MA}^{3}$}

\author{
${ }^{1}$ Universidad Autónoma Chapingo, Programa de Postgrado en Horticultura. Carretera México-Texcoco km. 38.5, \\ Chapingo, 56230, Estado de México, México. \\ ${ }^{2}$ Colegio Superior Agropecuario del Estado de Guerrero, Fitotecnia. Iguala Guerrero, 40000, Estado de Guerrero, \\ México. \\ ${ }^{3}$ Universidad Autónoma Chapingo, Programa de Postgrado en Protección Vegetal. Carretera México-Texcoco km. \\ 38.5, Chapingo, 56230, Estado de México, México. \\ ${ }^{4}$ Universidad Autónoma de Nuevo León, Facultad de Agronomía, Av. Universidad s/n, Cd. Universitaria San Nicolás \\ de los Garza, 66455, Nuevo León, México
}

Díaz-Nájera JF, Ayvar-Serna S, Vargas-Hernández M, Sahagún-Castellanos J, Alvarado-Gómez OG, Tejeda-Reyes MA 2018 - First report of squash leaf curl virus detected in Proboscidea louisianica in Mexico. Plant Pathology \& Quarantine 8(2), 140-143, Doi 10.5943/ppq/8/2/5

\begin{abstract}
Squash leaf curl virus (SLCV) was detected in Proboscidea louisianica and identified based on the nucleotide sequence of the viral capsid protein genome. Phylogenetic analysis confirmed that the begomovirus was associated with viral symptoms of the host weed. This is the first report of SLCV detected in P. louisianica.
\end{abstract}

Key words - begomovirus diagnosis - PCR - weed

\section{Introduction}

Geminiviruses are plant-infecting viruses which belong to the Geminiviridae family, with a characteristic circular, single-stranded DNA genome encapsulated in twin isometric particles, with single or bipartite components (DNA-A and DNA-B). The genus Begomovirus belongs to the Geminiviridae family, which is transmitted by the whitefly Bemisia tabaci (Al-Musa et al. 2008). It causes significant losses and affects dicotyledonous plants of high-valued horticultural crops (Polston et al. 2017). In addition to cultivated plants, begomoviruses are also found in weeds and wild plants. The identification of alternative hosts (weeds) is essential to completely understand the epidemiology of these infectious agents in developing more effective integrated pest management strategies; however, the importance of weeds in the cycle of viral diseases has been largely overlooked (Leke et al. 2015). Although recently, studies have been carried out on the begomoviruses that infect weeds (Polston et al. 2017). According to Mubin et al. (2010), weeds are reservoirs for begomovirus, they play a crucial role in the outbreak of epidemics that affect plants at the beginning of their cropping cycle. In the dry season, weeds serve as refuge for vectors, they are key factors in spreading many viruses, by redistributing primary inoculum and are an important factor in the epidemiology of begomovirus (Zaidi \& Mansoor 2017). The infected weeds may show 
few symptoms or be asymptomatic, making it more difficult to manage viral diseases in crops (Wisler \& Norris 2005). Therefore, the aim of this study was to analyze molecularly and phylogenetically the virus that affects $P$. louisianica.

\section{Materials \& Methods}

\section{Collected of weed, extraction of ADN, molecular identification and phylogenetic analysis}

Young leaves of Proboscidea louisianica (P. Mill.) Thell, commonly known as "Torito", with characteristic virus symptoms were collected. The symptoms included a bright yellow mosaic, epinasty, marginal leaf chlorosis (yellowing edges), leaf size reduction, leaf area reduction, dwarfism, and stunting. Samples were collected at the Experimental Field of the Agricultural College of the State of Guerrero (CSAEGro), located at Cocula, Guerrero (18 ${ }^{\circ} 14$ 'N, $99^{\circ} 39^{\prime} \mathrm{W}$ and $640 \mathrm{~m}$ above sea level). The climate is AW0, which corresponds to warm sub-humid with summer rains, with annual temperature and precipitation of $26.4{ }^{\circ} \mathrm{C}$ and $767 \mathrm{~mm}$, respectively. The samples were transported to the Phytosanitary Diagnostic Laboratory "Biociencia", located in Monterrey, Nuevo León, Mexico, where molecular analysis was carried out by extracting genomic DNA from $P$. louisianica leaves according to the DNeasy Plant Kit (QIAGEN ${ }^{\circledR}$ USA). A combination of degenerate primers was used for PCR, by amplifying the gene that encodes the capsid protein (Wyatt \& Brown 1996, Zhang et al. 2008). The degenerate primers prV324 (5'GCCYATRTAYAGRAAGCCMAG-3') and CoPR (5'- GANGSATGHGTRCADGCCATATA-3') were used to amplify a fragment of approximately $576 \mathrm{bp}$ using a program with an initial temperature of $94{ }^{\circ} \mathrm{C}$ for $4 \mathrm{~min}$, followed by 35 cycles of $94{ }^{\circ} \mathrm{C}$ for $60 \mathrm{sec}, 50{ }^{\circ} \mathrm{C}$ for $45 \mathrm{sec}, 72{ }^{\circ} \mathrm{C}$ for $45 \mathrm{sec}$, and final extension of $72{ }^{\circ} \mathrm{C}$ for $6 \mathrm{~min}$. For DNA amplification, a Thermo TM thermocycler was used and the visualization of the amplified products were performed by electrophoresis on $1 \%$ agarose gels at 62 volts for 5 minutes followed by 100 volts for 40 minutes, and were observed in a UVMR light transilluminator. Representative samples of the PCR products were sequenced and then compared to those in the GenBank database. The consensus sequences were edited and assembled using the CAP option (Contig Assembly Program) of the BioEdit Software 7.2.5 (Hall 2004). In the evolutionary analysis, all consensus sequences were aligned with the ClustalW program included in the MEGA 7 software (Kumar et al. 2016). Phylogenetic reconstructions for the data were performed by the maximum parsimony method, using the subtreepruning-regrafting algorithm, with search option (level $=1)$ in which the initial trees were obtained by random addition of sequences (10 replicates), the spaces or missing data were considered complete deletion. To calculate the confidence values of the clades, a bootstrap test was performed with 1000 replicates. The obtained sequence was deposited in the GenBank database.

\section{Results}

Viral syndrome was observed in Proboscidea louisianica plants: leaf deformation, roughness, yellow mosaics, leaf size reduction, chlorotic bulge, and marginal leaf chlorosis (Fig. 1). By PCR analysis and subsequent observation on agarose gels, the presence of Begomovirus was detected in leaf tissue of the "Torito" weed, considered endemic to the CSAEGro region, located in the community of Cocula Gro., in the northern part of the state of Guerrero, Mexico. This is congruent with the abundant population of whitefly detected on "Torito", weeds and squash plants (Cucurbita реро) established during the growing season (spring/summer 2015). The sequence of $494 \mathrm{bp}$ obtained from the amplified product showed 99\% similarity to the coding region for the capsid protein, with sequences reported in the Genbank for squash leaf curl virus. Subsequently, the sequence was deposited in the Genbank of the National Center for Biotechnology Information, accession number KX620944.1 DAM2 (Fig. 2). The phylogenetic analysis based on the encoding region of the capsid protein identified the virus as SLCV. In this region, the virus was grouped with its homologues (DQ285016 and DQ285019), with a bootstrap confidence level of 96\%, and is highly differentiated from the rest of the species (100\%) (Fig. 2). 


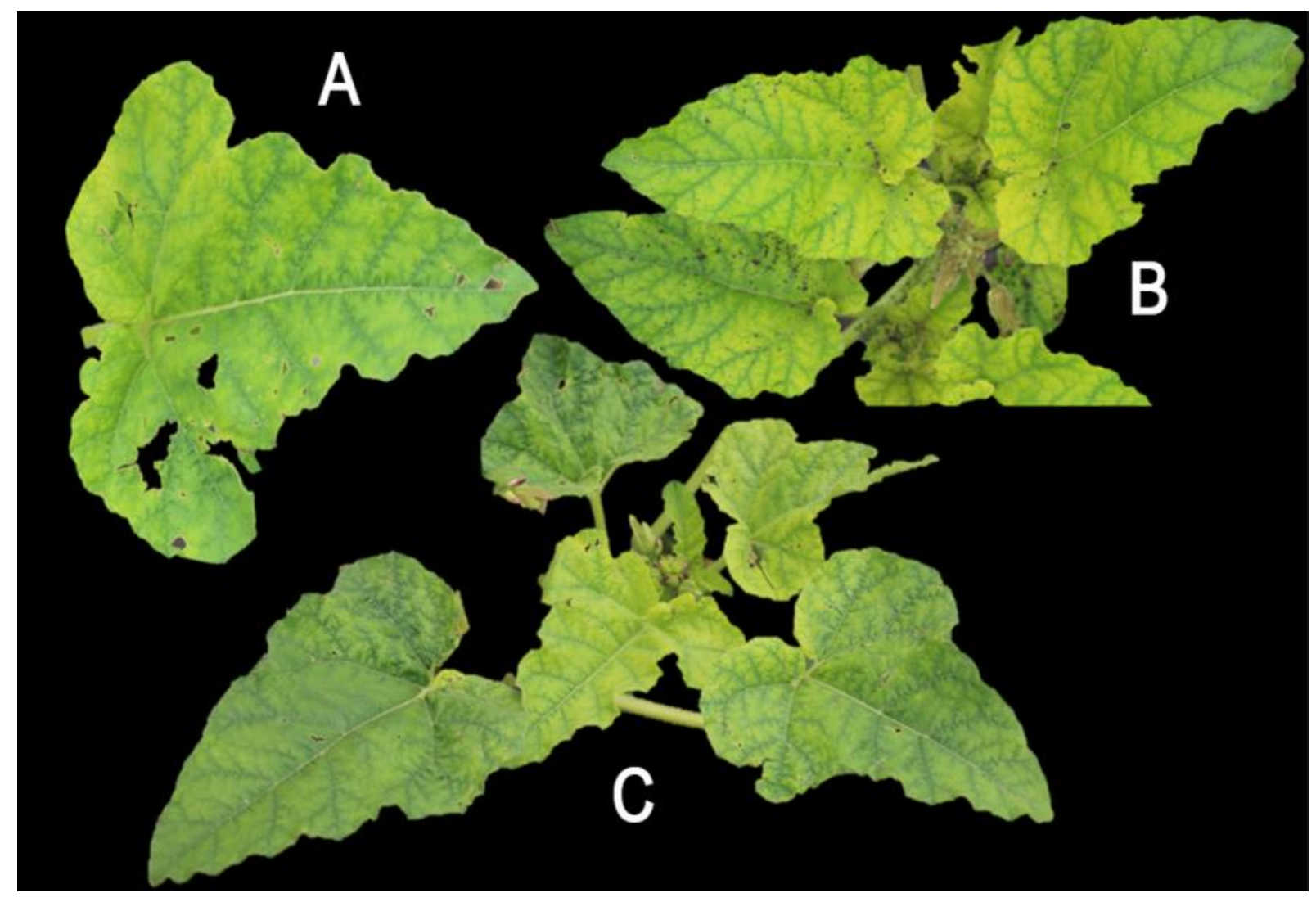

Fig. 1 - Squash leaf curl virus (A, B, and C) Symptoms of chlorosis, deformation, and mosaics associated with begomovirus infection in Proboscidea louisianica.

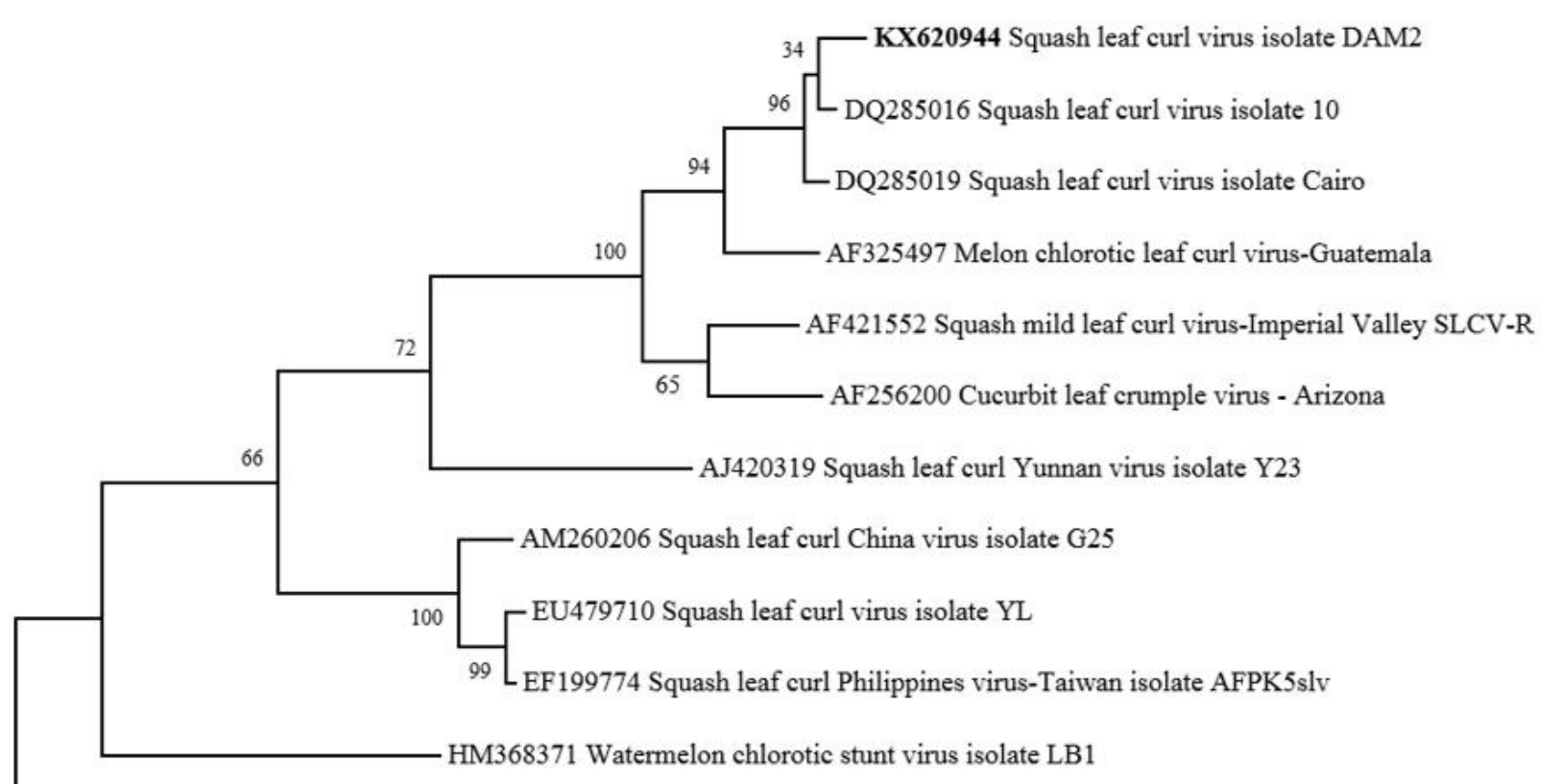

Y00514.1 Maize streak virus strain South African

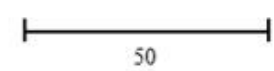

Fig. 2 - Phylogenetic tree obtained by the maximum parsimony method using the subtree-pruningregrafting algorithm. The confidence values of the nodes were formed with 1000 bootstrap replicates. Bold lettering represents the evaluated strain in this study. 


\section{Discussion}

"Torito" and other weeds play an important part in ecosystems of the northern region of Guerrero, and other parts of Mexico and North America. When harvesting ends, mainly vegetable crops, weeds are the main hosts and reservoirs of plant-infecting viruses and their insect vectors (Chen et al. 2013). Snehi et al. (2015) pointed out that by eradicating perennial weeds from around, inside, and outside greenhouses, eliminating possible virus inoculum sources in fields, and monitoring and detecting initial symptoms in the early stages of development of the crop, can be useful strategies to decrease the incidence of viral infections. In Pakistan, Mubin et al. (2010) studied the interaction of begomovirus and Sonchus arvensis by cloning, nucleic acid sequencing and phylogenetic analysis because according to these authors, the molecular diagnosis makes known the relationship of the virus and its host by also determines its correlation with other viruses of the same group detected in other parts of the world. On the other hand, according to Mauck et al. (2012) vectors have the tendency to be attracted to weeds and once they transmit the viruses, they present a pathogenic attenuation phase that does not kill the host (weed) which functions as a longterm food source for the vector (Zaidi \& Mansoor 2017).

\section{References}

Al-Musa A, Anfoka G, Misbeh S, Abhary M, Ahmad FH. 2008 - Detection and molecular characterization of squash leaf curl virus (SLCV) in Jordan. Journal of Phytopathology 156, 311-316.

Chen G, Pan H, Xie W, Wang S et al. 2013 - Virus infection of a weed increases vector attraction to and vector fitness on the weed. Scientific Reports 3, 2253. DOI: 10.1038/srep02253.

Hall T. 2004 - BioEdit version 7.0.0. Isis Pharmaceuticals 192 p. http://www.mbio.ncsu.edu/ BioEdit/biodoc.pdf.

Kumar S, Stecher G, Tamura K. 2016 - MEGA7: Molecular Evolutionary Genetics Analysis Version 7.0 for Bigger Datasets. Molecular Biology and Evolution 33(7), 1870-1874.

Leke WN, Mignouna DB, Brown JK, Kvarnheden A. 2015 - Begomovirus disease complex: emerging threat to vegetable production systems of West and Central Africa. Agriculture \& Food Security 4, 1. DOI 10.1186/s40066-014-0020-2.

Mauck K, Bosque PNA, Eigenbrode SD, De-Moraes CM, Mescher MC. 2012 - Transmission mechanisms shape pathogen effects on host-vector interactions: evidence from plant viruses. Functional Ecology. 26, 1162-1175.

Mubin M, Shahid MS, Tahir MN, Briddon RW, Mansoor S. 2010 - Characterization of begomovirus components from a weed suggests that begomoviruses may associate with multiple distinct DNA satellites. Virus Genes 40, 452-457.

Polston JE, Londoño MA, Cohen AL, Padilla-Rodriguez M et al. 2017 - Genome sequence of Euphorbia mosaic virus from passionfruit and Euphorbia heterophylla in Florida. Genome Announcements 5: e01714-16.

Snehi SK, Raj SK, Prasad V, Singh V. 2015 - Recent research findings related to management strategies of begomoviruses. Plant Pathology and Microbiology 6, 273. doi:10.4172/21577471.1000273.

Wisler GC, Norris RF. 2005 - Interactions between weeds and cultivated plants as related to management of plant pathogens. Weed Science 53, 914-917.

Wyatt SD, Brown JK. 1996 - Detection of subgroup III geminivirus isolates in leaf extracts by degenerate primers and polymerase chain reaction. Phytopathology 86, 1288-1293.

Zaidi SS, Mansoor S. 2017 - Viral vectors for plant genome engineering. Frontiers in Plant Science 8, 539. doi: 10.3389/fpls.2017.00539.

Zhang YP, Zhu MW, Cui HM, Qiu Y et al. 2008 - Molecular identification and the complete nucleotide sequence of TYLCV isolate from Shangai of China. Virus Genes 36, 547-551. 